\title{
EVALUATION OF EARLY MATURITY ASPECTS OF TWO EGYPTIAN NILE TILAPIA (Oreochromis niloticus) STRAINS: ABBASSA IMPROVED AND MANZALA COMMERCIAL WITHIN A DIALLEL CROSSING
}

\author{
M. M. Said
}

Aquaculture Department, Faculty of Fish Resources, Suez University, Suez, Egypt

\begin{abstract}
This study aims to evaluate the early maturity aspects of genetically improved strain Abbassa (AA), local commercial strain Manzala (MM), and their crosses within a complete diallel crossing. Mass spawning was practiced in replicate hapas to produce progeny from all possible genotypes (two pure strains and two crosses) for evaluation after a grow-out period of 20 weeks. Cross between Manzala males and Abbassa females (MA) showed the highest body weight and body length (24.98 g and $10.47 \mathrm{~cm}$, respectively) while the condition factor of $A A$ (2.25) was higher than all another genotypes. Body weight, body length, and condition factor were all significantly $(P<0.001)$ higher in males $(26.76 \mathrm{~g}, 10.5 \mathrm{Cm}$, and 2.31 , respectively) than females $(21.36 \mathrm{~g}, 10.09$ $\mathrm{cm}$, and 2.08, respectively). Males of AM cross ranked first in gonad weight and gonado-somatic index (GSI) (0.39 $\mathrm{g}$ and $0.75 \%$, respectively) whereas Abbassa strain was the lowest $(0.33 \mathrm{~g}$ and $0.64 \%$, respectively). The local commercial strain Manzala showed the highest gonad weight and GSI in females (0.58 $g$ and $1.26 \%$, respectively) followed with the two crosses whilst Abbassa strain females also showed the lowest records $(0.45 \mathrm{~g}$ and $0.99 \%$, respectively). Sex ratio (males to females) didn't differ significantly between the different genotypes. Length at which $50 \%$ of fish reaches sexual maturity $\left(L_{50}\right)$ was higher in AA for both of males and females $(11.4$ and $11.2 \mathrm{~cm}$, respectively) than MA cross $(10.8$ and $10.6 \mathrm{~cm}$, respectively) and MM (10.8 and $10.5 \mathrm{~cm}$, respectively) while AM cross showed the lowest $L_{50}$ in both sexes $(10.3$ and $10.1 \mathrm{~cm}$, respectively). The additive effect of Abbassa strain for condition factor was 0.09 while negative significant $(P<0.001)$ estimates for the additive effect of Abbassa were showed for gonad weight in females and GSI in females (-0.17g and $-0.28 \%$, respectively). Significant heterosis estimates were 0.15 and -0.05 in body length and condition factor, respectively. Reciprocal effects were significant in body weight, body length, gonad weight in males, and GSI in males. The results of the current study suggest that using crossbred brood stocks between Abbassa and Manzala strains at commercial hatcheries would be a good option that allows exploiting the high growth rate of Abbassa strain and heterosis of the growth without a negative impact on the early maturity aspects.
\end{abstract}

Keywords: Early maturity, Sex ratio, Gonad weight, Gonado-somatic index, Additive effect, Heterosis, Reciprocal effects

\section{INTRODUCTION}

Aquaculture production increased dramatically in Egypt during the last decade to represent $77 \%$ from the total fish resources production. Egyptian tilapia production represents about $57 \%$ of the total aquaculture production (GAFRD, 2014). Conducting a genetic improvement programs in order to develop genetically improved strains is a widely spread approach. Many improved tilapia strains had been produced to date as GIFT (Eknath et al., 1993and Eknath and Acosta, 1998), FAST (Bolivar, 1998), GET-EXCEL (Tayamen, 2004), and GST (GenoMar Supreme Tilapia), (Zimmerman and Natividad, 2004). In Egypt, WorldFish has developed the improved tilapia strain Abbassa (Rezk et al., 2009) which was introduced to the Egyptian aquaculture industry from 2012. Ibrahim et al. (2013) reported a notable superior growth rate of Abbassa strain as compared with local commercial strain. On the other hand, anecdotal information from hatchery managers has mentioned that Abbassa strain matures later than other commercial strains. The profit margins of the tilapia hatcheries in Egypt were somewhat small so, keeping the broodstock for a longer time until starting fry production will be costly. Some hatcheries have stopped using Abbassa and start to reuse the local commercial strains, which will lead to loose the growth benefits of Abbassa strain. The selection for growth rate and its implications on the sexual maturation had been studied without a clear conclusion (Uraiwan, 1988; Longalong et al., 1999; Mair et al., 2004 and Azhar et al., 2016).

In the present study, we investigated the early maturity aspects of Abbassa strain in a diallel crossing scheme with the commercial strain Manzala in order to explore the optimize use of Abbassa strain in the commercial tilapia hatcheries.

\section{MATERIALS AND METHODS}

\section{Origin of strains:}

This study involved two strains of Egyptian Nile tilapia: 1) Abbassa selection strain (AA), previously described by Rezk et al. (2009) and Khaw et al. (2009). Abbassa strain was obtained from WorldFish Regional Center, Abbassa, Abu-Hamad, Sharkia, Egypt. 2) Manzala local strain (MM) which obtained from a civil tilapia hatchery, located at Manzala, 
Dakahlia, Egypt. This study was carried out at a private fish hatchery from April to October, 2015.

\section{Fry production and rearing:}

Female and male breeders from the studied strains were conditioned in separate hapas ( 3 X 4 X $1 \mathrm{~m}$ ) for 3 weeks. Females and then males were transferred to breeding hapas $(1 \quad \mathrm{X} 2 \mathrm{2} \times 1 \mathrm{~m})$. All four possible genotypes combinations (two purebreds and two crosses) were formed with four replicates, each replicate contained two males and six females. After 2 weeks, swim-up fry were collected and 3000 fry from each genotype were randomly selected and transferred to nursing hapas $(1 \times 2 \times 1 \mathrm{~m})$ at a stocking density of 1000 fry / hapa for a nursery period (a total number of 12 hapas, three replicates for each genotype). After 4 weeks of nursing, a random sample of 200 fingerlings were selected from each hapa and transferred to post nursery hapa ( $3 \mathrm{X} 4$ $\mathrm{X} 1 \mathrm{~m}$ ) for further 6 weeks rearing. After such post nursery stage fish were transferred to rearing hapas (3 X 8 X $1 \mathrm{~m}$ ) for another 10 weeks.

\section{Fish Management:}

All experimental hapas were installed in $1200 \mathrm{~m}^{2}$ earthen pond which was in a static water system. About $20 \%$ of the water was daily exchanged to maintain good water characteristics. Water temperature ranged between 25 and $30^{\circ} \mathrm{C}, \mathrm{pH}$ value ranged between 7.3 and 8 , water salinity ranged between 2300 and $2700 \mathrm{mg} / \mathrm{L}$. Breeders were fed 2 $\%$ of their average body weight with a pelleted commercial feed containing 35\% crude protein. During the nursery stage, fry were fed ad libitum four times per day with a commercial powder feed containing $45 \%$ crude protein. After the initial nursing stage, fish were fed at $8 \%$ (6 weeks) and 5\% (10 weeks) of their body weight with commercial pellet containing $30 \%$ crude protein.

\section{Measured Traits:}

At the end of the experiment, 40 fish per hapa were randomly chosen and individually measured for body weight $(\mathrm{g})$ and body length $(\mathrm{cm})$. Condition factor was calculated according to the formula: $\mathrm{K}=$ (Weight (g) / Length $(\mathrm{cm})^{3}$ ) X 100 (Le Cren, 1951). Gonads of the chosen fish were weighed (g); gonadosomatic index (GSI) was calculated according to the formula GSI $\%$ = [weight of gonads (g) / body weight (g)] X 100 (De Vlaming et al., 1982); sex ratio (males and females \%) was determined for each hapa. The maturity stages of the fish gonads were determined through visual inspection of the appearance, size and texture, according to the scale adopted from Mous et al. (1995). Each fish was classified as either sexually immature or sexually mature based on the stage of development of its gonads. Fish that were grouped in maturity stages I, II were considered immature, while those with gonads in stages III, IV were considered mature, for the purpose of calculating the length at which $50 \%$ of fish population reaches sexual maturity $\left(\mathrm{L}_{50}\right)$. To estimate $\mathrm{L}_{50}$, the total body length was plotted against the frequency percentage of mature individuals, and then the length at which $50 \%$ of the total individuals number was consider as the length at first maturity (Shoko et al., 2015).

\section{Statistical analysis:}

To estimate the effect of the different genotypes on body weight, body length, and condition factor, a fixed effects model was used. The model included the effects of genotype (4 levels), sex (2 levels), and hapa nested within genotype (12 levels). The gonad weight and GSI were analyzed separately for each sex. The distributions of these traits were highly skewed. Square root transformation was used to overcome this problem. The model for the analysis of these traits included the genotype effect (4 levels) and the hapa nested within genotype (12 levels). Sex ratio data were analyzed using the chi square test (Zar, 1984). The comparisons between the least squares means of the genotypes were tested using Bonferroni test (Bonferroni, 1936). The least squares means of the gonad weight and GSI were back transformed to their original scale.

To estimate additive genetic, heterosis, and reciprocal effects of the complete diallel design. The analysis of covariance (ANCOVA) was used on body weight, body length, and condition factor. The model included the sex as a fixed effect and additive genetic, heterosis and reciprocal effects as covariates. The coding of these effects is shown in Table (1). For the gonad weight and GSI, the sex effect was excluded from the model and multiple regression analysis was used to estimate the crossbreeding parameters. This model included only the additive genetic, heterosis, and reciprocal effects and their coefficients were coded also as described in Table 1. The correlations between all studied traits were estimated. All analyses were done using SPSS 22 (IBM SPSS, 2013).

Table1. Illustration of coding for the coefficients of the additive genetic, total heterosis, and general reciprocal effects used in ANCOVA and multiple regression models.

\begin{tabular}{|c|c|c|c|c|c|c|}
\hline \multirow{2}{*}{$\begin{array}{r}\text { Strain /cross } \\
\qquad \hat{\delta} \times q\end{array}$} & \multirow{2}{*}{$\begin{array}{c}\text { Overall mean } \\
\mu \\
\end{array}$} & \multicolumn{2}{|c|}{ Additive genetic } & \multirow{2}{*}{$\begin{array}{l}\text { Total heterosis } \\
\mathrm{h}_{\mathrm{AXM} \text { or MXA }}\end{array}$} & \multicolumn{2}{|c|}{ General reciprocal } \\
\hline & & $\underline{\mathrm{a}}_{\mathrm{A}}$ & $\mathrm{a}_{\mathrm{M}}$ & & $\mathrm{r}_{\mathrm{A}}$ & $\mathrm{r}_{\mathrm{M}}$ \\
\hline AA X AA & 1 & 1.0 & 0.0 & 0.0 & 0.0 & 0.0 \\
\hline AA X MM & 1 & 0.5 & 0.5 & 1.0 & -0.5 & 0.5 \\
\hline MM X AA & 1 & 0.5 & 0.5 & 1.0 & 0.5 & -0.5 \\
\hline MM X MM & 1 & 0.0 & 1.0 & 0.0 & 0.0 & 0.0 \\
\hline
\end{tabular}

As in_Gjerde et al., 2002 


\section{RESULTS AND DISCUSSION}

Descriptive statistics and coefficients of correlation:

Table 2 has the descriptive statistics of body weight $(\mathrm{g})$, body length $(\mathrm{cm})$, condition factor, gonad weight (g), and GSI in two Egyptian Nile Tilapia strains (Abbassa and Manzala) and their crosses at 20 weeks old. Positive, moderate, and statistically significant $(\mathrm{P}<0.01)$ coefficients of correlation were recorded between gonad weight with both body weight and body length in males (0.61 and 0.55 , respectively) and females $(0.53$ and 0.54 , respectively). Similarly positive significant coefficients of correlation were listed between GSI and body weight; GSI and body length in males $(0.42$ and 0.4 respectively) and females $(0.42$ and 0.38 respectively). Gonad weight was highly correlated with GSI in both males and females (0.96 and 0.97, respectively). These results are in agreement with Sultan et al. (2011) who reported significant and positive correlation coefficients between tilapia body length and ovary weight ( 0.51$)$; body length and GSI (0.39); body weight and ovary weight $(0.61)$; body weight and GSI (0.42). The current results indicate that whenever males and females body weight or length increase, the gonads weight and GSI will be also increased.

Table 2. Descriptive statistics for body measurements, gonad weight, and gonado-somatic index (GSI \%) of two different Nile tilapia strains and their crosses at 20 weeks old.

\begin{tabular}{lcccccc}
\hline Trait & $\mathrm{N}$ & Minimum & Maximum & Mean & Std. Error & CV \% \\
\hline Body length $(\mathrm{cm})$ & 480 & 8.1 & 12.40 & 10.32 & .036 & 7.58 \\
Body weight $(\mathrm{g})$ & 480 & 13.56 & 43.35 & 24.33 & .216 & 19.40 \\
Condition factor. & 480 & 1.57 & 3.04 & 2.20 & .013 & 12.40 \\
Males gonad weight $(\mathrm{g})$ & 264 & 0.05 & 0.67 & 0.13 & .006 & 66.81 \\
Females gonad weight $(\mathrm{g})$ & 216 & .048 & 1.08 & 0.34 & .017 & 72.46 \\
GSI \% (males) & 264 & 0.18 & 1.88 & 0.50 & .016 & 53.32 \\
GSI \% (females) & 216 & 0.26 & 4.47 & 1.53 & .068 & 65.66 \\
\hline
\end{tabular}

\section{Growth parameters:}

Concerning body weight $(\mathrm{g})$, body length $(\mathrm{cm})$, and condition factor, results in Table 3 shows that the differences between the involved genotypes were significant $(\mathrm{P}<0.01)$ while the sex effect was highly significant $(\mathrm{P}<0.001)$. The cross between Manzala males and Abbassa females (MA) showed the highest body weight and body length (24.98 g and $10.47 \mathrm{~cm}$, respectively) followed by Abbassa purebred and AM cross while the commercial strain Manzala (MM) showed the lowest weight and length $(23.45 \mathrm{~g}$ and $10.21 \mathrm{~cm}$, respectively) (Table 4). These results were relatively in agreement with Maluwa and Gjerde (2006) who mentioned that five out of the six strain crosses showed a significant positive increment above the mean body weight of the purebred strains in Oreochromis shiranus. The superiority of the crosses genotypes could be explained as a result of the hybrid vigor between the two studied strains due to the genetic difference concerning growth traits. Condition factor of Abbassa (2.25) was higher than all other genotypes although it was ranked second for the body weight. The response to selection on growth rate seems to have a specific effect on the body confirmation of Nile tilapia which may explains the increment in condition factor of the selection strain Abbassa. The current results are in agreement with De Oliveira et al. (2016) who reported that the selection for growth rate in Oreochromis niloticus had a constant effect in body conformation, in the long term, the fish would have become rotund.

Table 3. Analysis of variance for body weight (g), body length (cm), and condition factor of different genotypes of 20 weeks old Nile tilapia according to fixed effects model.

\begin{tabular}{lcccccc}
\hline Source of Variance & \multicolumn{2}{c}{ Body weight } & Body & Length & \multicolumn{2}{c}{ Condition factor } \\
\cline { 2 - 7 } & Df & Sig. & Df & Sig. & Df & Sig. \\
\hline Genotype & 3 & $* *$ & 3 & $* *$ & 3 & $* *$ \\
Sex & 1 & $* * *$ & 1 & $* * *$ & 1 & $* * *$ \\
Hapa & 8 & $* * *$ & 8 & $* * *$ & 8 & $* * *$ \\
Total & 480 & & 480 & 480 &
\end{tabular}

Asterisks or Ns across classification indicate the significance or absence of it as a source of variation

$* * *=$ significant at $\mathrm{p} \leq 0.001 ; * *=$ significant at $\mathrm{p} \leq 0.01$ 
Table 4. Least squares means $( \pm \mathrm{SE})$ for body weight $(\mathrm{g})$, body length $(\mathrm{cm})$, and condition factor of different genotypes of 20 weeks old Nile tilapia according to fixed effects model

\begin{tabular}{lccc}
\hline Genotype & Body weight $(\mathbf{g})$ & Body length(cm) & Condition factor \\
\hline AA & $24.01^{\mathrm{ab}} \pm 0.34$ & $10.23^{\mathrm{ab}} \pm 0.06$ & $2.25^{\mathrm{a}} \pm 0.02$ \\
AM & $23.8^{\mathrm{ab}} \pm 0.34$ & $10.27^{\mathrm{a}} \pm 0.06$ & $2.18^{\mathrm{ab}} \pm 0.02$ \\
MA & $24.98^{\mathrm{a}} \pm 0.34$ & $10.47^{\mathrm{a}} \pm 0.06$ & $2.16^{\mathrm{b}} \pm 0.02$ \\
MM & $23.45^{\mathrm{b}} \pm 0.34$ & $10.21^{\mathrm{b}} \pm 0.06$ & $2.18^{\mathrm{ab}} \pm 0.02$ \\
\hline Sex & & & \\
\hline Males & $26.76^{\mathrm{a}} \pm 0.23$ & $10.5^{\mathrm{a}} \pm 0.04$ & $2.31^{\mathrm{a}} \pm 0.01$ \\
Females & $21.36^{\mathrm{b}} \pm 0.25$ & $10.09^{\mathrm{b}} \pm 0.05$ & $2.08^{\mathrm{b}} \pm 0.01$ \\
\hline
\end{tabular}

ab...Within classification any two means having the same script are not significantly different using Bonferroni test $\mathrm{p} \leq 0.05$.

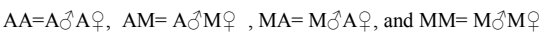

All studied growth traits including body weight $(\mathrm{g})$, body length $(\mathrm{cm})$, and condition factor were significantly higher in males $(26.76 \mathrm{~g}, 10.5 \mathrm{~cm}$, and 2.31) than females $(21.36 \mathrm{~g}, 10.09 \mathrm{~cm}$, and 2.08).This superiority of the growth of tilapia males $v s$. females was reported in many previous studies. Lind et al. (2015) found that the harvest body weight of Oreochromis niloticus females was 0.61 of the males body weight.

\section{First maturity aspects:}

Analysis of variance (Table 5) revealed that the effect of genotype was highly significant $(\mathrm{P}<0.001)$ for gonad weight and GSI in both males and females. Regarding gonad weight and GSI in males, AM cross ranked first $(0.39 \mathrm{~g}$. and $0.75 \%$, respectively) while Abbassa strain showed the lowest estimates $(0.33 \mathrm{~g}$ and $0.64 \%$, respectively). Manzala purebred showed the highest gonad weight and GSI in females $(0.58 \mathrm{~g}$ and $1.26 \%$, respectively) followed with the crosses the MA and AM, respectively. Similarly, as in males Abbassa strain, females also showed the lowest gonad weight and GSI records $(0.45 \mathrm{~g}$ and $0.99 \%)$ between all studied genotypes (Table 6). Gonad weight and GSI in the selection strain Abbassa were lower than Manzala commercial strain with about 6 and $7 \%$, respectively, in males and with 28 and 27 $\%$, respectively in females.

The results (Table 7) shows that the sex ratio (males and females \%) didn't differ significantly between the different genotypes. The overall males: females ratio was 55: $45 \%$. The highest males percentage was recorded in purebred genotypes AA and MM (57.5\%) followed with AM cross (55.8\%). MA cross showed the highest females ratio $(50.8 \%)$ followed with AM cross (44.2\%).

Table 5. Analysis of variance for gonad weight (g) and gonado-somatic index (GSI \%) of different genotypes of 20 weeks old Nile tilapia according to the fixed effects model

\begin{tabular}{|c|c|c|c|c|c|c|c|c|c|}
\hline \multirow[b]{2}{*}{ Source } & \multirow[b]{2}{*}{ of } & \multicolumn{4}{|c|}{ Gonad weight } & \multicolumn{4}{|c|}{ GSI $\%$} \\
\hline & & Df & Sig. & Df. & Sig. & Df & Sig. & $\overline{D f}$ & Sig. \\
\hline Genotype & & 3 & $* * *$ & 3 & $* * *$ & 3 & $* * *$ & 3 & $* * *$ \\
\hline Hapa & & 8 & $* * *$ & 8 & Ns & 8 & $* * *$ & 8 & Ns \\
\hline Total & & 264 & & 216 & & 246 & & 216 & \\
\hline
\end{tabular}

Asterisks or Ns across classification indicate the significance or absence of it as a source of variation; $* * *=$ significant at $\mathrm{p} \leq 0.001$.

Table 6. Least squares means $( \pm$ SE) for gonad weight $(g)$ and gonado-somatic index (GSI \%) of different genotypes of 20 weeks old Nile tilapia according to the fixed effect model

\begin{tabular}{lllll}
$\begin{array}{c}\text { Genotype } \\
(\hat{\partial} \mathrm{X})\end{array}$ & $\begin{array}{l}\text { Gonad weight } \\
(\text { males })\end{array}$ & $\begin{array}{l}\text { Gonad weight } \\
(\text { females })\end{array}$ & GSI (males) & GSI (females) \\
\hline AA & $0.33^{\mathrm{b}} \pm 0.01$ & $0.45^{\mathrm{b}} \pm 0.02$ & $0.64^{\mathrm{b}} \pm 0.01$ & $0.99^{\mathrm{b}} \pm 0.05$ \\
AM & $0.39^{\mathrm{a}} \pm 0.01$ & $0.55^{\mathrm{ab}} \pm 0.02$ & $0.75^{\mathrm{a}} \pm 0.01$ & $1.19^{\mathrm{ab}} \pm 0.05$ \\
MA & $0.34^{\mathrm{a}} \pm 001$ & $0.57^{\mathrm{a}} \pm 0.02$ & $0.66^{\mathrm{b}} \pm 0.01$ & $1.2^{\mathrm{a}} \pm 0.05$ \\
MM & $0.35^{\mathrm{ab}} \pm 0.01$ & $0.58^{\mathrm{a}} \pm 0.02$ & $0.69^{\mathrm{ab}} \pm 0.01$ & $1.26^{\mathrm{a}} \pm 0.05$ \\
\hline
\end{tabular}

$a b .$. Within classification any two means having the same script are not significantly different using Bonferroni test $\mathrm{p} \leq 0.05$.

Table 7. Chi Square test for sex ratio in two Egyptian Nile tilapia strains and their crosses at 20 weeks old

\begin{tabular}{lccc}
\hline & Value & Df & Asymp. Sig. (2-sided) \\
\hline Pearson Chi-Square & $2.290^{\mathrm{a}}$ & 3 & .515 \\
Likelihood Ratio & 2.283 & 3 & .516 \\
N of Valid Cases & 480 & & \\
\hline
\end{tabular}


The results (Fig. 1) indicate that the size at first maturity expressed as $\mathrm{L}_{50}$ was higher in the Abbassa selection strain (AA) for both of males and females (11.4 and $11.2 \mathrm{~cm}$, respectively) than MA cross (10.8 and $10.6 \mathrm{~cm}$, respectively) and Manzala commercial strain (MM) (10.8 and $10.5 \mathrm{~cm}$, respectively), while the AM cross showed the lowest $\mathrm{L}_{50}$ in both sexes (10.3 and $10.1 \mathrm{~cm}$, respectively). Furthermore, Abbassa selection strain showed lower percentage of mature fish in both males and females (48 and $49 \%$, respectively) than the commercial strain Manzala (51 and $53 \%$, respectively), while AM cross showed the highest percentage of mature fish between all involved genotypes (56 and 59\%, respectively). Results of the current study led to report notable disadvantages in the early maturation aspects in Abbassa strain including gonad weight, GSI, and size at maturation as compared with the commercial strain Manzala and the two possible crosses.

Falconer (1996) indicated that most phenotypic characters are correlated and that an improvement in one may result in positive or negative impact on other traits. So, the expected relationship in the present study between growth and maturity aspects may be explained as a result of negative genetic correlation. Some previous studies tried to focus on the relationship between growth and reproductive performance in tilapia and the impact of selection for growth rate on reproductive performance. Uraiwan (1988) demonstrated the evidence of genetic relationship between growth rate, age and size at maturity in tilapia. Furthermore, Longalong et al. (1999) had conducted a study on the selection for late maturation in the improved tilapia GIFT and they mentioned a correlated response in growth rate, the early maturing line grow faster than those later maturing line which gave more indication of possible negative relationship between growth and reproductive performance in tilapia. Mair et al. (2004) reported that hatchery managers in Thailand have indicated that the improved strain GIFT is later maturing than alternative unimproved strains which results in some hatcheries using only GIFT males as broodstock, to be crossed with earlier maturing females from a local strain. Further, they compared the reproductive parameters of three improved strains and a local commercial strain and reported that the improved strain GIFT sexually mature marginally later, have a lower absolute and relative fecundity, and have a lower GSI in males as compared with the local strain. In Egypt, similar unpublished information (personal communications) was pointed to a poor reproductive performance of the improved strain Abbassa especially in the first maturation stages. On the other hand, Azhar et al. (2016) studied the effect of selection for greater growth rate in the GIFT strain on other traits that related to female reproduction (weight at spawning, number of eggs, number of fry, total weight of fry and number of dead fry) and concluded that efficiency of reproduction per unit of weight of female did not change as a consequence of selection for growth. The current results showed that the first maturity aspects of Abbassa selection strain have a noted depression comparing with the commercial strain Manzala and their crosses. There are two prober explanations for such depression in Abbassa maturation characteristics. The selection for the growth performance in Abbassa strain for nine generations seems to be accompanied by undesirable correlated response in early maturation traits and /or the founding population of Abbassa may also have had bad reproductive performance from the beginning of the selection program.

\section{Diallel crossing analysis:}

The results of the diallel crossing analysis of variance (Tables 8 and 9) revealed that the additive effect of the selection strain Abbassa was significant for the condition factor $(\mathrm{P}<0.01)$ and highly significant $(\mathrm{P}<0.001)$ for both gonad weight in females, and GSI in females. Hetrosis effect was significant $(\mathrm{P}<0.01)$ for both body length and the condition factor. The reciprocal effects had a significant $(\mathrm{P}<0.01)$ effect on body weight, body length, gonad weight in males, and GSI\% in males (P $<0.001)$.

The diallel crossing parameter estimates (Tables 10 and 11) indicate a significant positive additive effect of Abbassa strain concerning the condition factor (0.09). Such positive additive effect for the improved strain Abbassa concerning the condition factor led to suggest the availability of improving the condition factor through selection procedures in Abbassa strain. Similar positive additive effect of different Oreochromis niloticus strains concerning the growth parameters were previously stated (Maluwa and Gjerde 2006; Pongthana et al., 2010; Ngo et al., 2016). On the other hand, significant negative additive effect of Abbassa strain were recorded for gonad weight in females and GSI in females $(-0.17 \mathrm{~g}$ and $0.28 \%$, respectively). The negative additive effect of Abbassa strain for these traits indicates the importance of evaluating the way of using such improved stain as female breeders in hatcheries. Heterosis estimates were 0.15 and -0.05 for body length and condition factor, respectively, which indicates high nicking ability between the studied strains concerning body length and purebred superiority concerning condition factor. These estimates led to suggest that the nonadditive genetic effects are likely to be important with respect to body length at 20 weeks old. The reciprocal effects estimates for body weight, body length, gonad weight in males, GSI in males were $1.17,0.21,-0.04$, and -0.09 , respectively which led to mention the significant differences between the two possible crosses concerning the these traits. The use of studied strains on crossing schemes in the future should take care of using each strain as male or female according to the recorded reciprocal effect estimates. 

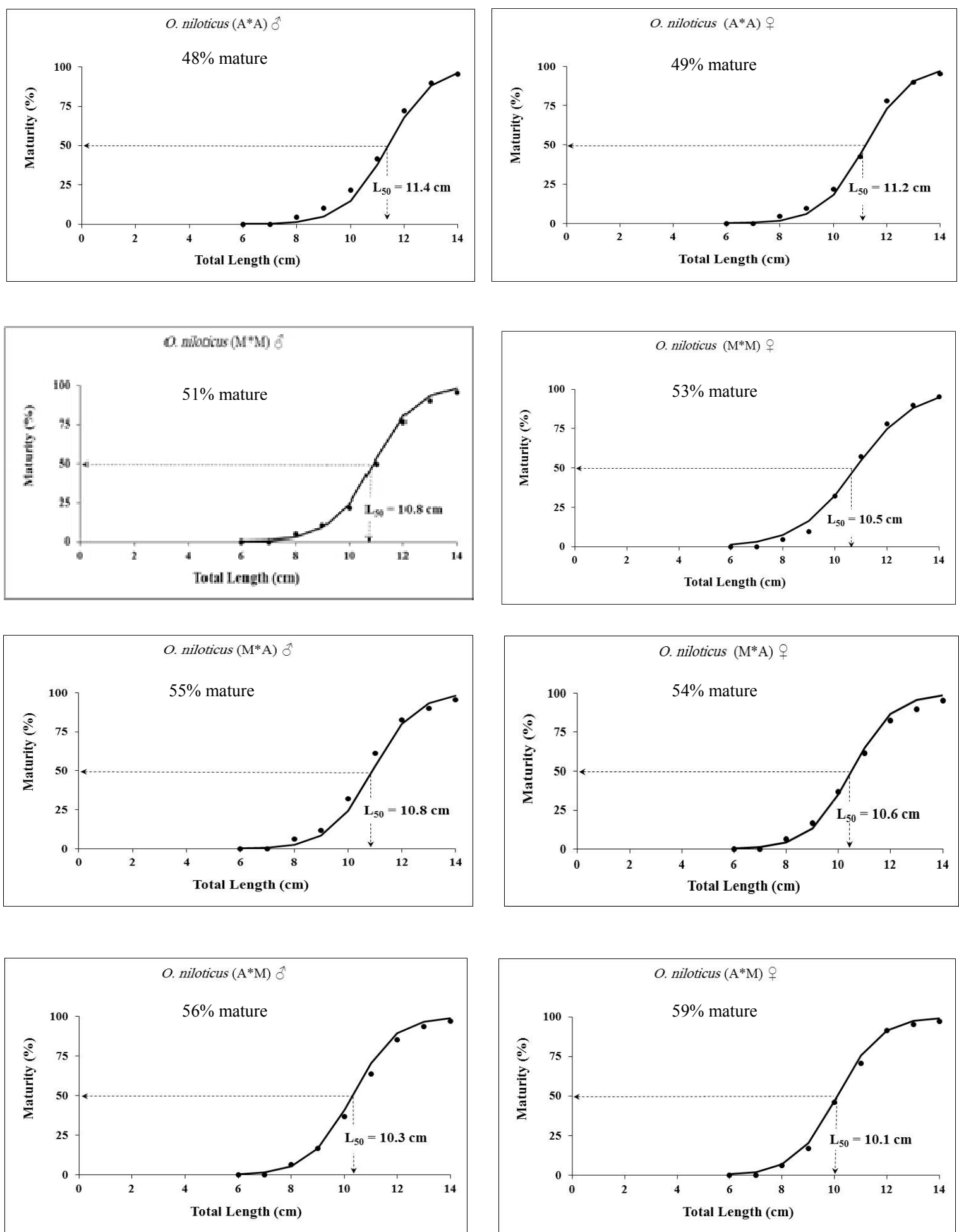

Fig. 1. 50\% maturation size $(\mathrm{cm})$ and \% of mature fish in two Egyptian Nile tilapia strains and their crosses at 20 weeks old. 
Table 8. Analysis of variance for body weight (g), body length (cm), and condition factor of 20 weeks old Nile tilapia from complete 2 X 2 diallel crossing according to ANCOVA model.

\begin{tabular}{|c|c|c|c|c|c|c|c|c|c|}
\hline \multirow[b]{2}{*}{$\begin{array}{l}\text { Source } \\
\text { variance }\end{array}$} & \multicolumn{3}{|c|}{ Body weight (g) } & \multicolumn{3}{|c|}{ Body length $(\mathrm{cm})$} & \multicolumn{3}{|c|}{ Condition factor } \\
\hline & Df & $\mathrm{SS}$ & Sig. & Df & $\mathrm{SS}$ & Sig & Df & $\mathrm{SS}$ & Sig. \\
\hline Additive A & 1 & 0.35 & Ns & 1 & 1.13 & Ns & 1 & 0.24 & $* *$ \\
\hline $\mathrm{He}$ & 1 & 8.01 & Ns & 1 & 2.64 & $* *$ & 1 & 0.27 & $* *$ \\
\hline Rec & 1 & 0.39 & $* *$ & 1 & 2.60 & $* *$ & 1 & 0.03 & Ns \\
\hline Sex & 1 & 82.8 & $* * *$ & 1 & 18.38 & $* * *$ & 1 & 6.5 & $* * * *$ \\
\hline Error & 475 & 3356.8 & & 475 & 271.1 & & 475 & 28.7 & \\
\hline Total & 480 & & & 480 & & & 480 & 480 & \\
\hline
\end{tabular}

Asterisks or Ns across classification indicate the significance or absence of it as a source of variation; $* *=$ significant at $\mathrm{p} \leq 0.01 ; * * *=$ significant at $\mathrm{p} \leq 0.001$.

Table 9. Analysis of variance for gonad weight (g) and gonado-somatic index (GSI \%) of 20 weeks old Nile tilapia from complete $2 \times 2$ diallel crossing according to multiple regression model.

\begin{tabular}{|c|c|c|c|c|c|c|c|c|c|c|c|c|}
\hline \multirow{2}{*}{$\begin{array}{l}\text { Source of } \\
\text { variance }\end{array}$} & \multicolumn{3}{|c|}{$\begin{array}{l}\text { Gonad weight } \\
\text { (Males) }\end{array}$} & \multicolumn{2}{|c|}{$\begin{array}{l}\text { Gonad weight } \\
\text { (Females) }\end{array}$} & \multicolumn{4}{|c|}{$\begin{array}{c}\text { GSI \% } \\
\text { (Males) }\end{array}$} & \multicolumn{3}{|c|}{$\begin{array}{c}\text { GSI\% } \\
\text { (Females) }\end{array}$} \\
\hline & Df & SS & Sig. & Df & $\mathrm{SS}$ & Sig & Df & SS & Sig. & Df & $\mathrm{SS}$ & Sig \\
\hline Additive A & 1 & 0.01 & Ns & 1 & 0.38 & $* * *$ & 1 & 0.03 & Ns & 1 & 1.08 & $* * *$ \\
\hline $\mathrm{He}$ & 1 & 0.04 & Ns & 1 & 0.11 & Ns & 1 & 0.1 & Ns & 1 & 0.32 & Ns \\
\hline Rec & 1 & 0.07 & $* *$ & 1 & 0.02 & Ns & 1 & 0.26 & $* * *$ & 1 & 0.00 & Ns \\
\hline Error & 260 & 2.8 & & 212 & 8.6 & & 260 & 7.1 & & & 212 & \\
\hline Total & 264 & & & 216 & & & 264 & & & & 216 & \\
\hline
\end{tabular}

Asterisks or Ns across classification indicate the significance or absence of it as a source of variation; $* *=$ significant at $\mathrm{p} \leq 0.01 ; * * *=$ significant at $\mathrm{p} \leq 0.001$

Table 10. Parameters estimates for body weight $(\mathrm{g})$, body length $(\mathrm{cm})$, and condition factor of 20 weeks old Nile tilapia from complete 2 X 2 diallel crossing according to ANCOVA model.

\begin{tabular}{llll}
\hline & Body weight $(\mathrm{g}) \pm \mathrm{SE}$ & Body length $(\mathrm{cm}) \pm \mathrm{SE}$ & Condition factor \pm SE \\
\hline Additive A & Ns & Ns & $0.09 \pm 0.04$ \\
$\mathrm{He}$ & $\mathrm{Ns}$ & $0.15 \pm 0.06$ & $-0.05 \pm 0.02$ \\
Rec & $1.17 \pm 0.5$ & $0.21 \pm 0.09$ & $\mathrm{NS}$ \\
\hline
\end{tabular}

Table 11. Parameters estimates for gonad weight (g) and gonado-somatic index (GSI \%) of 20 weeks old Nile tilapia from complete $2 \times 2$ diallel crossing according to multiple regression model.

\begin{tabular}{lllll}
\hline & \multicolumn{2}{c}{ Gonad weight \pm SE } & \multicolumn{2}{c}{ GSI\% $\%$ SE } \\
\hline Additive A & Ns & $-0.17 \pm 0.05$ & Ns & $-0.28 \pm 0.01$ \\
He & Ns & Ns & Ns & Ns \\
Rec & $-0.04 \pm 0.01$ & Ns & $-0.09 \pm 0.03$ & Ns \\
\hline
\end{tabular}

\section{CONCLUSION}

The results of the present study revealed that the first maturity aspects in Abbassa selection strain characterized with lower gonad weight, lower GSI, higher size at first maturity $\left(\mathrm{L}_{50}\right)$ as compared with the commercial strain Manzala and the two possible crosses. Significant negative additive effect estimates of Abbassa strain for gonad weight and GSI in females were listed in the diallel crossing analysis. These findings may lead to conclude that the use of such improved strain as a broods (especially females) in hatcheries should be accompanied with alternative breeding strategies with other commercial strains.

\section{ACKNOWLEDGMENTS}

I thank Dr. Wagdy Mekkawy for his constructive help, comments and suggestions.

\section{REFERENCES}

Azhar H., N. H. Nguyen, W. Mekkawy, H. L. Khaw, H. Y. Yee, K. R. Abu Bakar, R. W. Ponzoni, and S. A. Mohd Nor, 2016. Genetic parameters and correlated responses in female reproductive traits in the GIFT strain. Aquaculture Research, 47:1488-1498.

Bolivar, R. B., 1998. Estimation of response to withinfamily selection for growth in Nile tilapia $(O$. niloticus). PhD. Dissertation, Dalhousie University, Halifax, N.S., Canada, 166p.

Bonferroni, C. E., 1936. Teoria statistica delle classi e calcolo delle probabilità." Pubblicazioni del R Istituto Superiore di Scienze Economiche $\mathrm{e}$ Commerciali di Firenze 8, 3-62.

De Oliveira C.A., R.P. Ribeiro, G.M. Yoshida, N.M. Kunita, G.S. Rizzato, S.N. de Oliveira, A. I. Dos Santos, and N. H. Nguyen, 2016. Correlated changes in body shape after five generations of 
selection to improve growth rate in a breeding program for Nile tilapia Oreochromis niloticus. Brazil. J. Appl. Genet., 57(4):487-493.

De Vlaming V., G.D. Grossman, F. Chapman, 1982. On the use of the gonado-somatic index. Comp Biochem Physiol 73:31-39

Eknath, A. E., M. M. Tayamen, M. S. Palada-de Vera, J. C. Danting, R. A. Reyes, E. E. Dionisio, J. B. Capili, H. L. Bolivar, T. A. Abella, A. V. Circa, H. B. Bentsen, B. Gjerde, T. Gjedrem and R. S. V Pullin, 1993. Genetic improvement of farmed tilapias: the growth performance of eight strains of Oreochromis niloticus tested in different farm environments. Aquaculture 111: 171-188.

Eknath, A. E. and B. O. Acosta, 1998. Genetic improvement of farmed tilapias (GIFT) project: Final report, March 1988 to December 1997. International Center for Living Aquatic Resources Management, Makati City, Philippines.

Falconer, D.S. and T.F.C. Mackay, 1996. Quantitative Genetics. Longman, England, U.K. 464 pp.

GAFRD, 2014. General Authority for Fish Resources Development. Annual fishery statistics report, Ministry of Agriculture and Land Reclamation, Cairo, Egypt.

Ibrahim N. A., M. Y. Abou Zaid, L. K. Hooi, G. O. El-Naggar ., R. W. Ponzoni, 2013. Relative performance of two Nile tilapia (Oreochromis niloticus Linnaeus) strains in Egypt: The Abbassa selection line and the Kafr El Sheikh commercial strain. Aquaculture Research, 44: 508-517

Khaw H.L., H. Bovenhuis, R.W. Ponzoni., M.A. Rezk, H. Charo-Karisa, and H. Komen, 2009. Genetic analysis of Nile tilapia (Oreochromis niloticus) selection line reared in two input environments. Aquaculture, 294: 37-42.

Le Cren, E.D, 1951. The length-weight relationship and seasonal cycle in gonad weight and conditions in the perch Perca fluviatilis. J. Animal Ecol., London, 20 (2): 201-219.

Lind C.E., A. Safari, S. K. Agyakwah, F. Y. K. Attipoe, G. O. El-Naggar, A. Hamzah, G. Hulata, N. A. Ibrahim, H. L. Khaw, N. H. Nguyena, A. O. Maluwa, M. Zaid, T. Zake, and R. W. Ponzoni, 2015. Differences in sexual size dimorphism among farmed tilapia species and strains undergoing genetic improvement for body weight. Aquaculture Reports 1: 20-27.

Longalong, F. M., A. E. Eknath, and H. B. Bentsen, 1999. Response to bidirectional selection for frequency of early maturing females for Nile tilapia (Oreochromis niloticus). Aquaculture, 178: 13-25.

Mair, G., C. S. Lakapunrat1, W. L. Jere, and A. Bart, 2004. Comparisons of reproductive parameters among improved strains of Nile Tilapia Oreochromis niloticus L. Proceeding of the Sixth International Symposium on Tilapia in Aquaculture, Manila, Philippines (ed. by R. Bolivar, G. Mair \& K. Fitzsimmons).

Maluwa A.O. and B. Gjerde, 2006. Genetic evaluation of four strains of Oreochromis shiranus for harvest body weight in a diallel cross. Aquaculture 259: 28-37.

Mous, P. J., P. C. Goudswaard, E.F.B. Katunzi, Y.L. Budeba, F. Witte, and W. Ligtvoet, 1995. Sampling and measuring. In: Witte F, van Densen WLT (eds) Fish stocks and fisheries of Lake Victoria: a handbook for field observations. Samara Publishing House Limited, Samara House, Cardigan, Dyfed SA43 2JG., Great Britain, pp 5582.

Ngo P. T., H. N. Nguyen, T. H. Nguyen, K. Wayne, H. D. Nguyen, and H. N. Nguyen, 2016. Additive genetic and heterotic effects in a $4 \mathrm{X} 4$ complete diallel cross-population of Nile tilapia (Oreochromis niloticus, Linnaeus, 1758) reared in different water temperature environments in Northern Vietnam. Aquaculture Research, 47: 708-720.

Pongthana N., N.H. Nguyen, and R.W. Ponzoni, 2010. Comparative performance of four red tilapia strains and their crosses in fresh-and saline water environments. Aquaculture, 308: S109-S114.

Tayamen, M. M., 2004. Nationwide dissemination of GET-EXCEL tilapia in the Philippines, p74-88. In: R. B. Bolivar, G. C. Mair and K. Fitzsimmons (eds.). New dimensions of farmed tilapia, Proceedings from the Sixth International Symposium on Tilapia in Aquaculture, Manila, Philippines

Rezk M.A., R.W. Ponzoni, E. Kamel, G. John, T. Dawood, H.L. Khaw, and M. Megahed, 2009. Selective breeding for increased body weight in a synthetic breed of Egyptian Nile tilapia, Oreochromis niloticus: Response to selection and genetic parameters. Aquaculture, 293: 187-194.

Sultan, M. A., S. M., El-Laithy, G. O., El-Nagaar, and W. E., Mohammed, 2011. Effects of spawning month and pond protection on reproductive performance of Nile Tilapia Oreochromis niloticus. Proceedings of 29th Arab Veterinary Medical Congress, Cairo, Egypt, 433-450

Shoko, A. P., S. M. Limbu, H. D. J. Mrosso, and Y. D. Mgaya, 2015. Reproductive biology of female Nile tilapia Oreochromis niloticus (Linnaeus) reared in monoculture and polyculture with African sharptooth catfish Clarias gariepinus (Burchell). SpringerPlus, 4:275.

SPSS., 2013. IBM Corp. Released 2013. IBM SPSS Statistics for Windows, Version 22.0. Armonk, NY: IBM Corp.

Uraiwan, S., 1988. Direct and indirect responses to selection for age at first maturation of Oreochromis niloticus. pp. 295-300. In: Pullin, R.S.V., Bhukaswan, T., Tonguthai, K., and Maclean, J.L. (Eds.), The Second International Symposium on Tilapia in Aquaculture. Department of Fisheries, Thailand and International Center for Living Aquatic Resources Management, Bangkok.

Zar, J.H., 1984. Biostatistical Analysis, Second Edition. Prentice and Hall Inc., Englewood Cliffs New Jersey, pp. 62-65. 
Zimmermann, S. and J. M. Natividad, 2004. Comparative pond performance evaluation of GenoMar Supreme Tilapia ${ }^{\mathrm{TM}}$ GST1 and GST3 groups, p89. In: R. B. Bolivar, G. C. Mair and K.
Fitzsimmons (eds.). New dimensions of farmed tilapia, Proceedings from the Sixth International Symposium on Tilapia in Aquaculture, Manila, Philippines.

تقييم مظاهر النضج المبكر فى سلالاتين مصريتين من البلطى النيلى عباسه المحسنه ومنزله التجاريه خلال خلط متبادل

محمد محمد سعيل

قسم الاستزراع المائس، كليه الثروة السدكيه، جامعه السويس، السويس، مصر

الدراسة تهدف إلى تقييم مظاهر النضج المبكر فى السلالة المنتخبة عباسة (أل) و السلالة التجارية منزله (م م) والخلطان المككنة بينهما

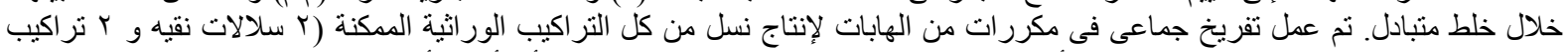

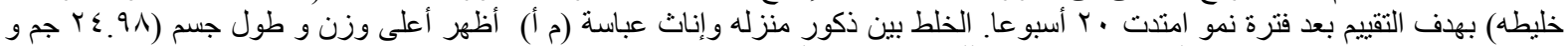

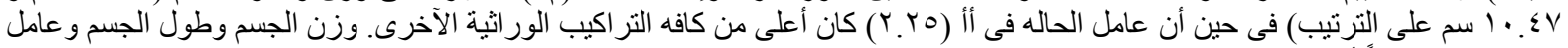

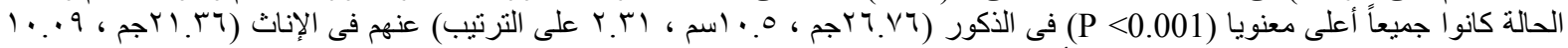

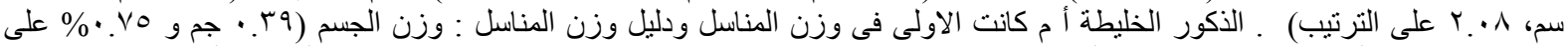

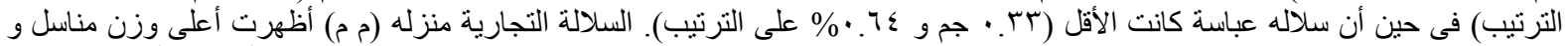

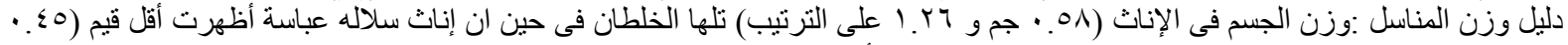

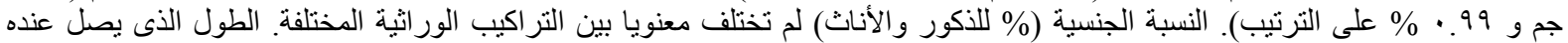

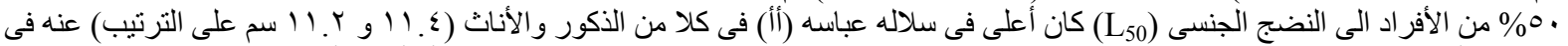

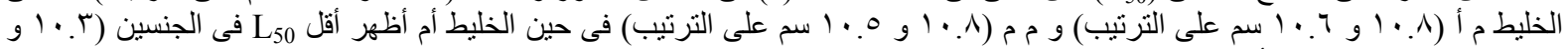

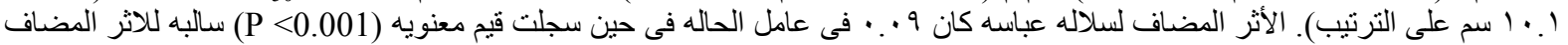

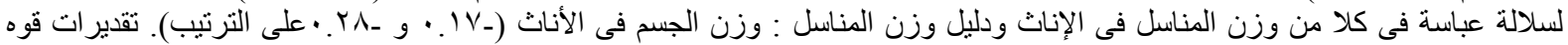

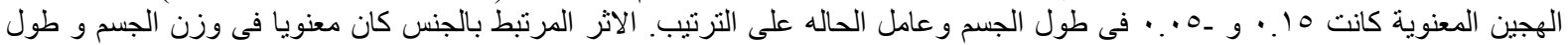

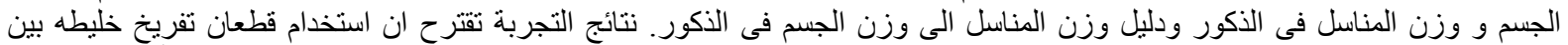

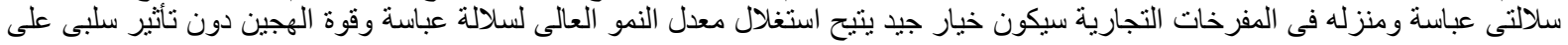

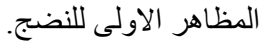

